\title{
Special Issue "International Academic MindTrek2008: Entertainment and Media in the Ubiquitous Era"
}

\author{
Artur Lugmayr · Frans Mäyrä · Heljä Franssila • \\ Katri Lietsala
}

Published online: 2 December 2009

(C) Springer-Verlag 2009

This special issue is devoted to a selection of papers from the 2nd International Academic MindTrek Conference that yearly takes place in Tampere, Finland. The conference was organized in cooperation between Tampere University of Technology (TUT), University of Tampere (UTA), and the MindTrek Association. The International Academic MindTrek 2008 Conference featured the theme "Entertainment and Media in the Ubiquitous Era" and was organized in three different tracks: ubicom, digital games, and social media.

The International Academic MindTrek 2008 Conference was in co-operation with ACM SIGMM, and ACM SIG$\mathrm{CHI}$ and attracted more than 800 attendees. MindTrek is special, as it brings together a cross-disciplinary crowd of people discussing media from business, social, technical, and content viewpoints. MindTrek features various activities, such as competition, business conference, and the academic conference.

\footnotetext{
A. Lugmayr $(\bowtie)$

EMMi Lab., Department of Business Information Systems and Logistics, Tampere University of Technology (TUT), Korkeakoulunkatu 8, P.O. Box 541, 33101 Tampere, Finland e-mail: lartur@acm.org

F. Mäyrä · H. Franssila

INFIM, Department of Information Studies and Interactive

Media, Tampere University (UTA), Kanslerinrinne 1,

33014 Tampere, Finland

e-mail: frans.mayra@uta.fi

H. Franssila

e-mail: helja.franssila@uta.fi

K. Lietsala

Gemilo Ltd, Rautatienkatu 21 A, 33100 Tampere, Finland

e-mail: katri.lietsala@gemilo.com
}

This special issue includes five papers, which are extended versions of their original submissions. The original submissions can be found in the ACM Digital Library together with the other conference papers. The authors origin from Australia, Finland, France, Spain, and Czech Republic, contributing their viewpoint to technological, social, and content aspects of entertainment media in the ubiquitous area.

As chairs of the Academic MindTrek Conference 2008, we congratulate the authors of the papers, which made it into the special issue - the selection was very competitive. We would like to thank the Program Committee of the MindTrek Conference, as their help made the conference possible. We especially would like to thank Prof. Thomas Plagemann in the position of the MSJ Editor-in-chief for giving us the possibility to publish selected papers within this issue. Special thanks also go to Prof. Brian Bailey for acting as 'shepherd' for this issue, thus his advices and help in the process of its creation.

Artur Lugmayr (General Chair)

Frans Mäyrä, Heljä Franssila, and Katri Lietsala (Co-Chairs) 